\title{
PENGARUH GAYA KEPEMIMPINAN DAN KUALITAS PRODUK TERHADAP PRODUKTIFITAS KERJA KARYAWAN SPRAY PAINTING METAL DI PT.RAPALA VMC BATAM
}

\author{
Rona Tanjung \\ Program Studi Manajemen , FakultasEkonomi, Universitas Kepulauan Riau \\ Ronatanjung07@gmail.com
}

\begin{abstract}
Abstrak
Penelitian ini bertujuan untuk meneliti pengaruh gaya kepemimpinan terhadap produktivitas kerja karyawan, pengaruh kualitas produk terhadap produktivitas kerja karyawan, dan pengaruh gaya kepemimpinan dan kualitas produk terhadap produktivitas kerja karyawan spray painting PT. Rapala VMC Batam.Penelitian ini mengambil sample sebanyak 28 orang. Pengumpulan data menggunakan kuesioner yang telah di uji validitas dan reabilitasnya.Hasil penelitian ini menunjukkan bahwa terdapat pengaruh positif antara gaya kepemimpinan terhadap produktivitas kerja ditunjukan dengan hasil uji . Dengan nilai t hitung 3.071>t table 2.059 dan dengan nilai signifikan sama besar dengan 0.05. Tidak terdapat pengaruh kualitas produk terhadap produktivitas kerja karyawan.Dengan nilai $t$ hitung $1.656<t$ tabel 2.059 dengan taraf signifikansi hitung sebesar 0.110 tersebut lebih besar dari 0.05.Terdapat pengaruh gaya kepemimpinan dan kualitas produk secara simultan terhadap produktivitas kerja karyawan, hak ini ditunjukkan dengan hasil uji $F$. Dengan nilai $F$ hitung $=163.884$ yang menggunakan batas signifikansi 0.05, maka diperoleh nilai signifikansi tersebut lebih kecil dari 0.05 yaitu 0.000 .
\end{abstract}

\section{Karyawan}

Kata kunci: Gaya Kepemimpinan, Kualitas Produk, dan Produktivitas Kerja 
PENDAHULUAN

\section{Latar Belakang Masalah}

Pada dasarnya tujuan perusahaan adalah untuk menjaga kelangsungan hidup perusahaan, kemajuan dan kesejahteraan karyawan serta pemiliknya. Sedangkan tujuan individu memasuki perusahaan atau organisasi adalah untuk memenuhi kebutuhan hidupnya. Tujuan individu harus diselaraskan dengan tujuan perusahaan melalui kepemimpinan dan bimbingan. Tanpa kepemimpinan dan bimbingan hubungan dan tujuan individu dengan tujuan perusahaan menjadi renggang atau lemah. Keadaan ini menyebabkan tidak terarahnya tujuan individu dan perusahaan tidak efisien.

Perusahaan harus dapat memiliki produktivitas yang baik untuk memenuhi target perusahaan yang sudah ditetapkan. Kinerja karyawan yang baik dengan etos kerja yang tinggi akan membantu perusahaan untuk dapat memenuhi target perusahaan tersebut dan membantu perusahaan memperoleh keuntungan, sedangkan bila kinerja karyawan menurun dan buruk maka akan merugikan perusahaan tersebut.

Salah satu sumber daya organisasi yang memiliki peran penting dalam mencapai tujuannya adalah sumber daya manusia. Oleh karena itu, maka perlu adanya perhatian khusus agar kinerja karyawan dapat maksimal. Kinerja karyawan yang menurun tentu akan sangat mempengaruhi stabilitas perusahaan. Dimana karyawan dengan kinerja yang buruk, semangat kerja yang kurang akan membuat target perusahaan menjadi tidak tercapai sehingga perusahaan akan sulit untuk bersaing dengan perusahaan lain dan pada akhirnya dapat juga mengalami kebangkrutan jika tidak segera diberikan solusi yang tepat untuk menghadapi masalah kinerja tersebut.
Dalam

meningkatkan produktivitas karyawan, perusahaan telah melakukan berbagai macam cara seperti upah sesuai dengan UMR, tambahan insentif, dan pemberian bonus setiap tahunnya. Dukungan dari setiap manajemen yang berupa pengarahan, dukungan sumber daya seperti: memberikan peralatan yang memadai sebagai sarana untuk memudahkan pencapaian tujuan yang ingin dicapai dalam pekerjaan, bimbingan, pelatihan serta pengembangan akan lebih mempermudah peningkatan produktivitas kerja karyawan. Dukungan pengarahan manangemen dapat disampaikan melalui pemimpin produksi masing- masing departemen. Dimana setiap pemimpin memiliki cara dan gaya tersendiri dalam melakukan pengarahan dan memberikan semangat kepada karyawan untuk mengahasilkan tujuan perusahaan, yang dapat mempengaruhi hasil produktivitas kerja setiap karyawan.

Didalam pasar global yang berubah secara terus menerus, selain pengiriman yang cepat, kualitas produk juga menjadi salah satu elemen yang penting bagi perusahaan untuk dapat bersaing. Setiap perusahaan dapat meningkatkan kinerjanya melalui perbaikan berkelanjutan pada aktivitas bisnis yang terfokus pada konsumen, yakni meliputi keseluruhan organisasi dan penekanan pada fleksibilitas dan kualitas. Karena itu, kualitas dan pengolaannya selalu dikaitkan dengan aktivitas perbaikan berkelanjutan.

Perusahaan Rapala VMC adalah perusahaan yang bergerak dibidang manufaktur yang menghasilkan produk-produk pancing dan umpan-umpan pancing.Grup Rapala VMC merupakan salah satu perusahaan yang memiliki jaringan distribusi terbesar dengan merek produk yang paling diminati.Dan salah satu cabang perusahaan ini adalah PT.Rapala VMC Batam yang beralamat di Jl.Beringn Lot 206 BIP Muka Kuning Batam. 
PT.Rapala VMC Batam sendiri mengolah produksi bagian umpan pancing dengan berbagai jenis produk dan memiliki warna yang bervariasi sesuai permintaan dari pelanggan. Salah satu proses produksi di perusahaan ini adalah proses pewarnaan produk (spray paint) yang dilakukan oleh manusia. Dimana pada proses produksi ini diperlukan kemampuan untuk menstandartkan atau konsistensi warna sesuai dengan contoh warna yang diberikan.

Pencapaian produk yang berkualitas, perusahaan harus dapat mempertahankan efisiensi biaya dan meningkatkan kualitas produk tanpa adanya kenaikan biaya sehingga harga jual tetap kompetitif, hal ini disebabkan karena tidak adanya pengerjaan ulang produk tersebut.Oleh karena itu, manajemen perusahaan harus mampu menyeimbangkan peningkatan kualitas dengan produktivitas. Berikut pengambilan data output karyawan spray painting metal pada bulan April 2017

Kadir (2001:19), menyatakan bahwa kualitas adalah tujuan yang sulit dipahami (tujuan yang sulit dipahami), karena harapan para konsumen akan selalu berubah. Setiap standar baru ditemukan, maka konsumen akan menuntut lebih untuk mendapatkan standar baru lain yang lebih baru dan lebih baik. Dalam pandangan ini, kualitas adalah proses dan bukan hasil akhir (meningkatkan kualitas kontinuitas).

Pengertian produk itu sendiri menurut $\mathrm{H}$. Djaslim Saladin, SE. dalam bukunya yang berjudul Unsur-unsur Inti Pemasaran dan Manajemen Pemasaran (2003:45) : terbagi dalam beberapa pengertian, yaitu :

a. dalam pengertian sempitnya, produk adalah sekumpulan sifat-sifat fisik dan kimia yang berwujud yang dihimpun dalam suatu bentuk serupa dan yang telah dikenal.

b. Dalam pengertian secara luas, produk adalah sekelompok sifat-sifat yang berwujud (tangible) dan tidak berwujud (intangible) yang didalamnya sudah tercakup warna, harga, kemasan, prestise pabrik, prestise pengecer, dan pelayanan yang diberikan konsumen dan pengecer yang dapat diterima konsumen sebagai kepuasan yang ditawarkan terhadap keinginan atau kebutuhan konsumen.

c. Secara umumnya, produk itu diartikan secara ringkas sebagai segala sesuatu yang dapat memenuhi dan memuaskan kebutuhan atau keinginan manusia, baik yang berwujud maupun tidak berwujud.

Dari pengertian kualitas dan produk diatas dapat disimpulkan pengertian dari kualitas produk adalah standar kesesuaian harapan atas segala kebutuhan atau keinginan manusia atau konsumen.

\section{Faktor-faktor yang Mempengaruhi Kualitas Produk}

Menurut Mullins, Orville, Larreche, dan Boyd (2005, p.422) apabila perusahaan ingin mempertahankan keunggulan kompetitifnya dalam pasar, perusahaan harus mengerti aspek dimensi apa saja yang digunakan oleh konsumen untuk membedakan produk yang dijual perusahaan tersebut dengan produk pesaing.

Dimensi kualitas produk tersebut terdiri dari :

1. Performance (kinerja), berhubungan dengan karakteristik operasi dasar dari sebuah produk.

2. Durability (daya tahan), yang berarti berapa lama atau umur produk yang bersangkutan bertahan sebelum produk tersebut harus diganti. Semakin besar frekuensi pemakaian konsumen terhadap produk maka semakin besar pula daya tahan produk.

3. Conformance to specifications (kesesuaian dengan spesifikasi), yaitu sejauh mana karakteristik operasi dasar dari sebuah produk memenuhi 
spesifikasi tertentu dari konsumen atau tidak ditemukannya cacat pada produk.

4. Features (fitur), adalah karakteristik produk yang dirancang untuk menyempurnakan fungsi produk atau menambah ketertarikan konsumen terhadap produk.

5. Reliabilty (reliabilitas), adalah probabilitas bahwa produk akan bekerja dengan memuaskan atau tidak dalam periode waktu tertentu. Semakin kecil kemungkinan terjadinya kerusakan maka produk tersebut dapat diandalkan.

6. Aesthetics (estetika), berhubungan dengan bagaimana penampilan produk bisa dilihat dari tampak, rasa, bau, dan bentuk dari produk.

7. Perceived quality (kesan kualitas), sering dibilang merupakan hasil dari penggunaan pengukuran yang dilakukan secara tidak langsung karena terdapat kemungkinan bahwa konsumen tidak mengerti atau kekurangan informasi atas produk yang bersangkutan. Jadi, persepsi konsumen terhadap produk didapat dari harga, merek, periklanan, reputasi, dan Negara asal.

Adapun faktor-faktor yang mempengaruhi kualitas produk, menurut Feigenbaum (2000 : 7) adalah :
a. Market (pasar)
b. Money (uang)
c. Management (manajemen)
d. Man (manusia)
e. Motivation (motivasi)
f. Materials(bahan)

g. Machine and mechanisation (mesin dan mekanisasi)

\section{Data Output karyawan spray painting metal PT.Rapala VMC Batam pada Bulan April 2017}

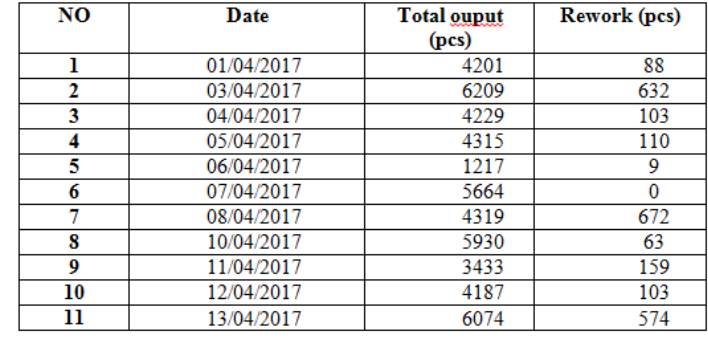

Menurut Thoha (2013:49) bahwa Gaya kepemimpinan merupakan norma perilaku yang digunakan oleh seseorang pada saat orang tersebut mencoba mempengaruhi perilaku yang ia lihat.

Sedangkan Rivai (2014:42) menyatakan Gaya kepemimpinan adalah sekumpulan cirri yang digunakan pimpinan untuk mempengaruhi bawahan agar sasaran organisasi tercapai atau dapat pula dikatakn bahwa gaya kepemimpinan adalah pola perilaku dan strategi yang disukai dan sering diterapkan oleh seorang pemimpin. Gaya kepemimpinan yang menunjukkan, secara langsung maupun tidak langsung, tentang keyakinan searang pempinan terhadap kemampuan bawahannya. Artinya gaya kepemimpinan adalah perilaku dan strategi, sebagai hasil kombinasi dari falsafah, keterampilan, sifat, sikap, yang sering diterapkan seorang pemimpin ketika ia mencoba mempengaruhi bawahannya.

Menurut Hersey dan Blanchard dikutip oleh Rivai (2014:16) menyatakan bahwa hubungan antara pemimpim dan anggotanya mempunyai empat tahap/fase yang diperlukan bagi pimpinan untuk mengubah gaya kepemimpinannya yaitu: tahap pertama, pada kesiapan awal perhatian pimpinan pada tugas sangat tinggi, anggota diberi instruksi yang jelas dan dibiasakan dengan peraturan, struktur dan prosedur kerja. Tahap kedua adalah dimana anggota sudah mampu menangani tugasnya, perhatian pada tugasnya sangat penting karena bawahan belum dapat bekerja tanpa 
struktur.Kepercayaan pimpinan pada bawahan semakin meningkat

Menurut ISO-8402 (Loh, 2001:35), Kualitas adalah totalitas fasilitas dan karakteristik dari produk atau jasa yang memenuhi kebutuhan, tersurat maupun tersirat.Tjiptono (2004:11), Mendefinisikan kualitas sebagai kesesuaian untuk digunakan (fitness untuk digunakan). Definisi lain yang menekankan orientasi harapan pelanggan pertemuan.Kadir (2001:19), menyatakan bahwa kualitas adalah tujuan yang sulit dipahami (tujuan yang sulit dipahami), karena harapan para konsumen akan selalu berubah. Setiap standar baru ditemukan, maka konsumen akan menuntut lebih untuk mendapatkan standar baru lain yang lebih baru dan lebih baik. Dalam pandangan ini, kualitas adalah proses dan bukan hasil akhir (meningkatkan kualitas kontinuitas).

Menurut Sunyoto (2013) secara filosofis produktivitas merupakan sikap mental yang selalu berusaha dan mempunyai pandangan bahwa suatu kehidupan hari ini lebih baik dari hari kemarin dan hari esok lebih baik dari hari ini.

Menurut (Hasibuan, 2010:128) produktivitas kerja merupakan perbandingan yang dimiliki baik secara perorangan ataupun tim didalam organisasi tersebut. Sedangkan menurut (Wibowo, 2011:109) produktivitas adalah hubungan antara keluaran atau hasil organisasi dengan masukan yang diperlukan. Namun menurut (Sutrisno, 2011:207) produktivitas merupakan output per unit, atau output dibagi input, atau rasio antara output dengan input.

\section{Kerangka Konseptual}

\section{Pengaruh Gaya kepemimpinan terhadap Produktivitas kerja karyawan}

Gaya kepemimpinan merupakan cara yang digunakan oleh pemimpin perusahaan untuk mempengaruhi atau memberikan arahan kepada bawahannya dalam arti dalam memberikan pekerjaan, masukan, motivasi untuk melakukan tanggung jawab dalam pekerjaannya,

Dengan melalui gaya kepemimpinan seorang pemimpin dapat memotivasi karyawan untuk melakukan pekerjaan yang dapat mendorong produktivitas kerja karyawan.

\section{Pengaruh Kualitas Produk terhadap produktivitas kerja karyawan}

Pada dasarnya kualitas produk akan berbeda-beda sesuai dengan kebutuhan dari pihak yang membutuhkan. Apabila terlalu menekan peningkatan kualitas produk akan menimbulkan biaya operasional yang tinggi dan sebaliknya apabila menekan peningkatan produktivitas akan menghasilkan kualitas produk yang rendah yang akan mempengaruhi turunnya produktivitas (output) produksi.

3. Pengaruh Gaya kepemimpinan dan Kualitas Produk terhadap produktivitas kerja karyawan

Apabila seorang pemimpin mampu meningkatkan semangat dan kegairahan kerja karyawan, maka diharapkan produktivitas kerjanya akan meningkat. Sebaliknya, apabila seorang pemimpin tidak mampu meningkatkan semangat dan kegairahan kerja karyawan, maka produktivitasakan menurun, tingkat absensi akan meningkat, tingkat disiplin akan menurun, dan adanya hal-hal yang merugikan perusahaan.

Pencapaian produk yang berkualitas, perusahaan harus dapat mempertahankan efisiensi biaya dan meningkatkan kualitas produk tanpa adanya kenaikan biaya sehingga harga jual tetap kompetitif, hal ini disebabkan karena tidak adanya pengerjaan ulang produk tersebut.Manajemen perusahaan harus mampu menyeimbangkan peningkatan kualitas dengan produktivitas. 


\section{Variabel Penelitian}

\section{METODOLOGI PENELITIAN}

Dalam penelitian ini yang dijadikan sampel adalah karyawan spray painting metal PT.Rapala Vmc Batam berjumlah 28 orang.instrumen penelitian dengan skala likert. Pengumpulan data menggunakan kuesioner yang telah di uji validitas dan reabilitasnya

\section{Populasi}

Populasi adalah keseluruhan subjek penelitian (Arikunto 2010:173) populasi adalah wilayah generalisasi yang terdiri atas obyek atau subyek, yang mempunyai kualitas dan karakteristik tertentu yang ditetapkan oleh peneliti untuk dipelajari dan ditarik kesimpulan (Sugiyono).Dalam penelitian ini yang menjadi populasi adalah karyawan spray painting metal di PT. Rapala VMC Batam yang berjumlah 30 orang.

Sampel adalah bagian dari jumlah dan karakteristik yang dimiliki oleh populasi tersebut (Sugiyono, 2012 :116). Sampel adalah bagian dari jumlah karateristik yang dimiliki oleh populasi tersebut (Sugiyono, 2009:115). Menurut Muri (2005:186) sampel adalah sebagian dari populasi yang terpilih dan mewakili dari populasi tersebut. Sampling yang dilakukan mempertimbangkan ketentuanketentuan dalam pengambilan sampel, yaitu sampel harus dapat mewakili populasi dan karakteristiknya.

Dalam penelitian ini yang dijadikan sampel adalah karyawan spray painting metal PT.Rapala Vmc Batam berjumlah 28 orang. Menurut Suharsimi (2002:113) apabila jumlah populasi kurang dari 100 orang, maka lebih baik keseluruhan populasi diambil dijadikan sampel. Pengambilan sampel dalam penelitian ini adalah dengan tekniktotal sampling yaitu metode pemilihan sampel yang diaplikasikan pada seluruh anggota populasi.
Variabel pada dasarnya adalah segala sesuatu yang berbentuk apa saja yang ditetapkan oleh peneliti untuk dipelajari sehingga diperoleh informasi tentang hal tersebut, kemudian ditarik kesimpulannya (Sugiyono,2012:56) adapun jenis variabel sebagai berikut :

\section{Variabel dependen}

Variabel dependen juga sering disebut dengan variabel terikat yaitu merupakan variabel yang mempengaruhi atau menjadi akibat karena adanya variabel independen. Variabel dependen (Y) dalam penelitian ini adalah produktivitas kerja karyawan spray painting metal pada PT.Rapala VMC Batam.

\section{Variabel independen}

Variabel independen juga sering disebut variabel bebas yaitu merupakan variabel yang mempengaruhi atau menjadi sebab perubahannya atau timbulnya variabel dependen.Variabel bebas dalam penelitian ini adalah Gaya Kepemimpinan (X1) dan kualitas produk (X2).

\section{Instrumen Penelitian}

Instrumen ini berguna untuk mengumpulkan data dalam penelitian yaitu dengan menggunakan beberapa pernyataan yang disusun dengan menggunakan skala likert. Skala likert adalah skala yang digunakan secara luas yang meminta responden menandai derajat persetujuan atau ketidak setujuan terhadap masing-masing serangkaian pernyataan mengenai objek situmulus ( Malhotra 2006:298).

Setiap butir pernyataan mempunyai 5 alternatif sebagai berikut:

a. SS ( Sangat Setuj ) diberi Skor $=5$

b. S (Setuju) diberi skor $=4$

c. KS (Kurang Setuju ) diberi skor $=3$ 
d. TS ( Tidak Setuju ) diberi skor $=2$

e. STS (Sangat Tidak Setuju ) diberi skor $=1$

\subsection{Sumber Data}

Sumber data yang digunakan dalam penelitian ini sebagai berikut:

\subsubsection{Data Primer}

Data primer adalah data yang diperoleh langsung dari lapangan. Data primer dari penelitian ini adalah data yang dikumpulkan secara langsung berupa hasil kuesioner responden berupa pengaruh gaya kepemimpinan dan kualitas produk terhadap produktivitas kerja karyawan spray painting metal PT. Rapala VMC Batam.

\subsubsection{Data skunder}

Data skunder adalah data yang diperoleh dari perusahaan yang dapat dilihat dari dokumentasi perusahaan, buku-buku referensi dan informasi lainnya yang berhubungan dengan penelitian.

\subsection{Metode Pengumpulan Data}

Metode yang digunakan untuk mengumpulkan data dalam penelitian ini adalah sebagai berikut:

\section{Kuesioner}

Pengumpulan data dengan cara ini dilakukan dengan menyebarkan kuesioner kepada responden yang telah ditentukan sebelumnya mengenai gaya kepemimpinan dan kualitas produk terhadap produktivitas kerja karyawan spray painting metal PT. Rapala VMC Batam. Dengan tujuan untuk memperoleh jawaban-jawaban yang digunakan sebagai data dalam penelitian.

\subsection{Uji Validitas dan Realibitas}

Data yang didapat akan dilakukan pengujian terhadap instrumen yang akan digunakan. Pengujian instrumen dalam penelitian ini meliputi uji validitas data, reliabilitas data dan normalitas data dengan menggunakan program software product and service solution (SPSS) 20.

\subsubsection{Uji Validitas}

Vailiditas adalah suatu ukuran yang menunjukan tingkat-tingkat ke validan atau sesahihan suatu instrumen, suatu instrumen yang valid atau sahih mempunyai validitas tinggi, sebaliknya instrumen yang kurang valid mempunyaivaliditas rendah. (Arikunto, 2010:211)

Rumus yang digunakan untuk mengukur validitasinstrumen dalam penelitian ini adalah rumus korelaso product moment, sebagai berikut:

$$
r_{x y}=\frac{N\left(\sum X Y\right)-\left(\sum X\right)\left(\sum Y\right)}{\sqrt{\left(N\left(\sum X^{2}\right)-\left(\sum X\right)^{2}\left(N\left(\sum Y^{2}\right)-\left(\sum Y\right)^{2}\right)\right)}}
$$

Keterangan :

rxy : Koefisien Korelasi

N : Jumlah Responden / Subjek

$\mathrm{X}$ : Skor Butir

Y : Skor total (Arikunto, 2010)

Pengambilan keputusan :

a. Jika $\mathrm{r}$ hitung positif dan $\mathrm{r}$ hitung $>$ 0,300 , maka butir pertanyaan valid

b. Jika $\mathrm{r}$ hitung negatif dan $\mathrm{r}$ hitung $<$ 0,300 , maka butir pernyataam tidak valid

c. r hitung dapat dilihat pada kolom corrected item-total correlation.

\subsubsection{Uji Reliabilitas}

Uji reliabilitas adalah uji untuk menunjukan sejauh mana suatu hasil pengukuran suatu relatif konsisten apabila pengukuran diulangi dua kali atau lebih. tujuan utama pengujian reabilitas adalah untuk mengetahui konsistensi atau keteraturan hasil pengukuran suatu instrumen apabila instrumen digunakan lagi sebagai alat ukur suatu objek atau responden (Sarwono,2006 dalam Hermawan 2012). Dalam penelitian ini menggunakan teknik Alpha cronbach yang dikerjakan dengan paket statistik software product and service solution (SPSS) dengan menggunakan rumus sebagai berikut :

$$
r_{11}=\left(\frac{K}{K-1}\right)\left(1-\frac{\sum \sigma_{i}^{2}}{\sigma_{\mathrm{t}}^{2}}\right)
$$


Keterangan :

K : Banyaknya butir pertanyaan atau banyaknya soal

$\sum \alpha b^{2} \quad$ Jumlah varians butir

$\alpha \mathrm{t}^{2} \quad$ : Varians total (Arikunto, 2010)

Pengambilan keputusan :

a. Jika $r$ alpha positif dan $r$ alpha $>0,600$, maka pertanyaan reliabel

b. Jika $r$ alpha negatif dan $r$ alpha $<0,600$, maka pertanyaan tidak reliabel.

c. $\mathrm{r}$ alpha dapat dilihat pada bagian reliabiliti coefficient.

\subsection{Metode Analisis Data}

\subsubsection{Uji Asumsi Klasik}

Metode ini mempunyai kriteria bahwa pengamatan harus mewakili variasi minimum, konstanta dan efisien. Asumsi BLUE yang harus dipenuhi antara lain: tidak ada multikoloneritas, tidak terjadi heteroskedastistas dan data berdistribusi normal.

\subsubsection{Uji Multikolinearitas}

Uji Multikolinearitas merupakan uji keadaan dimana terjadi hubungan linier yang sempurna atau mendekati sempurna antar variabel bebas dalam model regresi (Dwi Priyanto, 2010). Model regresi yang baik seharusnya tidak terjadi korelasi diantara variable bebas. Multikolineritas dapat dilihat dari (1) nilai tolerance dan lawannya (2) Variance Inflation Factor (VIF). Kedua ukuran ini menunjukkan setiap variable bebas manakah yang dijelaskan oleh variable bebas lainnya. Tolerance mengukur varibilitas variable bebas yang terpilih yang tidak dijelaskan oleh variable bebas lainnya. Jadi nilai tolerance yang rendah sama dengan nilai VIF yang tinggi. Nilai cut off yang umum dipilih untuk menunjukkan adanya multikolinearitas adalah nilai tolerance $<0.10$ atau sama dengan niali $F>10$ (Ghozali, 2005 dalam Hermawan,2012).

\subsubsection{Uji Heteroskedastisitas}

Uji Heteroskedastisitas adalah dimana terjadi varian variabel pada model regresi yang tidak sama, jika varian variabel pada model regresi memiliki nilai yang sama maka disebut dengan Homoskedastisitas dan jika varian berbeda disebut Heteroskedastisitas (Suliyanto, 2011:95). Deteksi ada atau tidaknya heteroskedastisitas dapat juga dilakukan dengan melihat ada tidaknya pola tertentu (bergelombang, melebar kemudian menyempit) pada grafik plot (Scatterplot) antara nilai prediksi variabel terkait (ZPRED) dengan residualnya (SRESID). Model regresi yang baik adalah yang Homoskedastisitas atau tidak terjadi Heteroskedastisitas

\subsubsection{Uji Normalitas}

Uji normalitas data di lakukan untuk mengetahui apakah data yang diperoleh normal atau tidak. Uji normalitas yang dilakukan terhadap sampel dilakukan dengan menggunakan kolmogorov-smirnov test dengan menetapkan derajat keyakinan $(\alpha)$ sebesar 5\%. Uji ini dilakukan pada setiap variabel dengan ketentuan bahwa jika secara individual masing-masing variabel memenuhi asumsi normalitas, maka secara simultan variabel-variabel tersebut juga bisa dinyatakan memenuhi asumsi normalitas ( Latan, 2013:56). Kriteria pengujian dengan meliihat bersama kolmogorov-smirnov test adalah:
a. Jika signifikasi >0,05 maka data tersebut berdistribusi normal.
b. Jika signifikasi <0,05 maka data tersebut tidak berdistribusi normal.

\subsubsection{Analisis Regresi Linear Berganda}

Analisis Regresi Linear Berganda merupakan salah satu analisis yang bertujuan untuk mngetahui pengaruh suatu variabel terhadap variabel lain. Dalam analisis regresi variabel yang mempengaruhi disebut independent variable (variabel bebas) dan variabel yang mempengaruhi disebut 
dependent variable(variabel terikat). Jika dalam persamaan regresi hanya terdapat salah satuvariabel bebas dan satu variabel terikat, maka disebut sebagai regresi sederhana, sedangkan jika variabelnya bebasnya lebih dari satu, maka disebut sebagai persamaan regresi berganda (Prayitno, 2010). Untuk mengetahui menganalisis pengaruh Disiplin kerja dan Motivasi kerja terhadap kinerja karyawan yang dilakuka Hotel Lovina Inn digunakan analisis regresi linier berganda (Prayitno, 2010);

$$
\begin{gathered}
Y= \\
+b_{1} X_{1}+b_{2} X_{2}+e
\end{gathered}
$$

Keterangan :

Karakteristik pada masingmasing variabel

$$
\begin{aligned}
& a=\begin{array}{c}
\text { konstanta atau besarnya } \\
\text { koefisien masing-masing } \\
\text { variabel sama dengan nol }
\end{array} \\
& \mathrm{b}_{1}=\text { besarnya pengaruh Disiplin } \\
& \mathrm{b}_{2}=\text { besarnya pengaruh Motivasi } \\
& \mathrm{X}_{1}=\begin{array}{c}
\text { Kepemimpinan } \mathrm{X}_{2}= \\
\text { variabel Kualitas produk }
\end{array} \\
& \mathrm{Y}=\text { kinerja } \\
& \mathrm{e}=\text { faktor gangguan }
\end{aligned}
$$

\subsubsection{Uji Hipotesis}

Uji hipotesis digunakan untuk mengetahui signifikasi dari masingmasing variabel bebas terhadap variabel terikat yang terdapat dalam model. Uji hipotesis yang dilakukan adalah ;

\subsubsection{Uji t}

Analisis ini digunakan untuk membuktikan signifikan tidaknya antara variabel menganalisis pengaruh Disiplin kerja dan Motivasi kerja terhadap Produktifitas karyawan oleh Hotel Lovina Inn adalah (Prayitno, 2010:68) :

$$
t=\frac{b i}{s e(b i)}
$$

Keterangan :

$\mathrm{t}=$ test signifikan dengan angka korelasi

$$
\text { bi }=\text { koefisien regresi }
$$

Se $(\mathrm{bi})=$ standard error

dari koefisien korelasi

Formulasi hipotesis uji $\mathrm{t}$;
$>$ Ho : bi $0, \mathrm{i}=1,2$

$\mathrm{H} 0$ diterima dan Ha ditolak, tidak ada pengaruh secara parsial (individu) antara variabel bebas $(\mathrm{X})$ terhadap variabel terikat $(\mathrm{Y})$

$>$ Ha : bi $0, \mathrm{i}=1,2$

$\mathrm{H}$ o ditolak dan $\mathrm{Ha}$ diterima, ada pengaruh secara parsial (individu) antara variabel bebas (X) terhadap variabel terikat (Y)

$>$ Level of significane 5\% (Uji 2 3.8.3.2 Uji F sisi, $5 \%: 2=2,5 \%$ atau 0,025 )

Uji $F$ digunakan untuk melihat signifikansi pengaruh dari variabel bebas secara simultan (serentak) terhadap variabel terikat (Prayitno,2010:67). Dalam penelitian ini uji $F$ digunakan untuk melihat signifikansi pengaruh dari variabel $\mathrm{X}_{1}, \mathrm{X}_{2}$ secara simultan terhadap variabel $\mathrm{Y}$. Rumus yang akan digunakan adalah :

$$
F=\frac{R^{2} /(k-1)}{1-R^{2} /(n-k)}
$$

Keterangan:

$\mathrm{F}=$ pengujian secara simultan

$\mathrm{R}_{2}=$ koefisien determinasi

$\mathrm{k}$ = banyaknya variabel

$\mathrm{n}=$ banyaknya sampel

Formulasi hipotesis uji $\mathrm{F}$;

$>\mathrm{Ho}_{\mathrm{b}} \mathrm{b} 1, \mathrm{~b}_{2}, 0$

$\mathrm{H} 0$ ditolak dan $\mathrm{Ha}$ diterima, ada pengaruh secara simultan antara varibel bebas $\left(\mathrm{X}_{1}, \mathrm{X}_{2}\right)$ terhadap varibel terikat $(\mathrm{Y})$

$>\mathrm{Ha}_{\mathrm{a}}: \mathrm{b}_{1}, \mathrm{~b}_{2},=0$

Ho diterima dan Ha ditolak, tidak ada pengaruh simultan antara varibel bebas $\left(\mathrm{X}_{1}, \mathrm{X}_{2}\right)$ terhadap varibel terikat $(\mathrm{Y})$

$>$ Level of significane $5 \%$.

\subsubsection{Uji $\mathbf{R}_{2}$ Koefisien Determinasi}

Koefisien determinasi adalah data untuk mengetahui seberapa besar 
prosentase pengaruh langsung variabel bebas yang semakin dekat hubungannya dengan variabel terikat atau dapat dikatakan bahwa penggunaan model tersebut bisa dibenarkan. Dari koefisiensi determinasi ( $\left.\mathrm{R}_{2}\right)$ dapat diperoleh suatu nilai untuk mengukur besarnya sumbangan dari beberapa variabel $X$ terhadap variasi naik turunnya variabel Y (Prayitno,).

$$
R^{2}=\sum \mathrm{Y}=
$$

$\frac{b^{1} \Sigma X_{1} Y+b^{2} \Sigma X_{2} Y+b 3 \Sigma X_{3} Y+b^{4} \Sigma X_{4} Y}{\Sigma Y^{2}}$

$$
\Sigma \mathrm{Y}^{2}
$$

Keterangan:

$\mathrm{R} 2$ = Koefisien determinasi berganda

$\mathrm{Y}=$ Variabel terikat (dependent)

$\mathrm{X}=$ Variabel bebas

(Independent)

\section{PEMBAHASAN}

Pengelompokan Responden Berdasarkan Jenis Kelamin

\begin{tabular}{|c|l|c|c|}
\hline No & Jenis Kelamin & Responden & Persentase (\%) \\
\hline 1 & Laki-laki & 28 orang & $100 \%$ \\
\hline 2 & Perempuan & - & $0 \%$ \\
\hline & Jumlah & 28 orang & $100,0 \%$ \\
\hline
\end{tabular}

Pengelompokan responden berdasarkan usia

\begin{tabular}{|c|c|c|c|}
\hline No & Usia & Responden & Persentase (\%) \\
\hline 1 & $<30$ tahun & - & $0 \%$ \\
\hline 2 & $24-30$ tahun & 2 orang & $7,1 \%$ \\
\hline 3 & $18-23$ tahun & 26 ornag & $92,9 \%$ \\
\hline & Jumlah & 28 orang & $100 \%$ \\
\hline
\end{tabular}

Pengelompokan responden berdasarkan responden

\begin{tabular}{|c|c|c|c|}
\hline No & Usia & Responden & Persentase (\%) \\
\hline 1 & SMU & 28 orang & $100 \%$ \\
\hline 2 & D3 & - & $0 \%$ \\
\hline 3 & S1 & - & $0 \%$ \\
\hline & Jumlah & 28 orang & $100 \%$ \\
\hline
\end{tabular}

\section{Pengelompokan Responden Berdasarkan Upah Kerja}

\begin{tabular}{|c|c|c|c|}
\hline NO & $\begin{array}{c}\text { Penghasilan } \\
\text { perbulan }\end{array}$ & Responden & Persentase (\%) \\
\hline 1 & $2,9 \mathrm{jt}-3,5 \mathrm{jt}$ & 24 orang & $85,7 \%$ \\
\hline 2 & $3,6 \mathrm{jt}-5 \mathrm{jt}$ & 4 orang & $14,3 \%$ \\
\hline 3 & $>5 \mathrm{jt}$ & - & $0 \%$ \\
\hline & & & $100,0 \%$ \\
\hline & Jumlah & 28 orang & 100 \\
\hline
\end{tabular}

Tanggapan Responden Mengenai Gaya

\begin{tabular}{|c|c|c|c|c|c|c|c|}
\hline \multirow[t]{2}{*}{ No } & \multirow[t]{2}{*}{ Pemyataan } & \multicolumn{5}{|c|}{ Jawaban } & \multirow[t]{2}{*}{ Jumlah } \\
\hline & & STS & TS & KS & $\mathrm{S}$ & SS & \\
\hline \multirow[t]{2}{*}{1} & \multirow[t]{2}{*}{$\mathrm{X} 1.1$} & & & 8 & 12 & 8 & 28 \\
\hline & & $0 \%$ & $0 \%$ & $29 \%$ & $43 \%$ & $29 \%$ & $100 \%$ \\
\hline \multirow[t]{2}{*}{2} & \multirow[t]{2}{*}{$\mathrm{X} 1.2$} & & & 9 & 10 & 9 & 28 \\
\hline & & $0 \%$ & $0 \%$ & $32 \%$ & $36 \%$ & $32 \%$ & $100 \%$ \\
\hline \multirow[t]{2}{*}{3} & \multirow[t]{2}{*}{$\mathrm{X} 1.3$} & 3 & & 8 & 8 & 9 & 28 \\
\hline & & $11 \%$ & $0 \%$ & $29 \%$ & $29 \%$ & $32 \%$ & $100 \%$ \\
\hline \multirow[t]{2}{*}{4} & \multirow[t]{2}{*}{$\mathrm{X} 1.4$} & 2 & & 9 & 9 & 8 & 28 \\
\hline & & $7 \%$ & $0 \%$ & $32 \%$ & $32 \%$ & $29 \%$ & $100 \%$ \\
\hline \multirow[t]{2}{*}{5} & \multirow[t]{2}{*}{$\mathrm{X} 1.5$} & & 3 & 5 & 10 & 10 & 28 \\
\hline & & $0 \%$ & $11 \%$ & $18 \%$ & $36 \%$ & $36 \%$ & $100 \%$ \\
\hline \multirow[t]{2}{*}{6} & \multirow[t]{2}{*}{$\mathrm{X} 1.6$} & & 2 & 3 & 12 & 11 & 28 \\
\hline & & $0 \%$ & $7 \%$ & $11 \%$ & $43 \%$ & $39 \%$ & $100 \%$ \\
\hline \multirow[t]{2}{*}{7} & \multirow[t]{2}{*}{$\mathrm{X} 1.7$} & & 2 & 3 & 10 & 13 & 28 \\
\hline & & $0 \%$ & $7 \%$ & $11 \%$ & $36 \%$ & $46 \%$ & $100 \%$ \\
\hline \multirow[t]{2}{*}{8} & \multirow[t]{2}{*}{$\mathrm{X} 1.8$} & & & 4 & 10 & 14 & 28 \\
\hline & & $0 \%$ & $0 \%$ & $14 \%$ & $36 \%$ & $50 \%$ & $100 \%$ \\
\hline \multirow[t]{2}{*}{9} & \multirow[t]{2}{*}{$\mathrm{X} 1.9$} & & 2 & 2 & 12 & 12 & 28 \\
\hline & & $0 \%$ & $7 \%$ & $7 \%$ & $43 \%$ & $43 \%$ & $100 \%$ \\
\hline \multirow[t]{2}{*}{10} & \multirow[t]{2}{*}{$\mathrm{X} 1.10$} & & & 3 & 13 & 12 & 28 \\
\hline & & $0 \%$ & $0 \%$ & $11 \%$ & $46 \%$ & $43 \%$ & $100 \%$ \\
\hline \multicolumn{2}{|c|}{ JUMLAH } & 5 & 9 & 54 & 106 & 106 & 280 \\
\hline \multicolumn{2}{|c|}{ PERSEN } & $2 \%$ & $3 \%$ & $19 \%$ & $38 \%$ & $38 \%$ & $100 \%$ \\
\hline
\end{tabular}
Kepemimpinan

Tanggapan Responden Mengenai Kualitas Produk 


\begin{tabular}{|c|c|c|c|c|c|c|c|}
\hline \multirow[t]{2}{*}{ NO } & \multirow[t]{2}{*}{ Pernyataan } & \multicolumn{5}{|c|}{ Jawaban } & \multirow[t]{2}{*}{$\mathrm{JuI}$} \\
\hline & & STS & TS & KS & $\mathrm{S}$ & SS & \\
\hline \multirow[t]{2}{*}{1} & \multirow[t]{2}{*}{$\mathrm{X} 2.1$} & & & 3 & 13 & 12 & \\
\hline & & $0 \%$ & $0 \%$ & $11 \%$ & $46 \%$ & $43 \%$ & 10 \\
\hline \multirow[t]{2}{*}{2} & \multirow[t]{2}{*}{$\mathrm{X} 2.2$} & & & 4 & 13 & 11 & \\
\hline & & $0 \%$ & $0 \%$ & $14 \%$ & $46 \%$ & $39 \%$ & 10 \\
\hline \multirow[t]{2}{*}{3} & \multirow[t]{2}{*}{$\mathrm{X} 2.3$} & 1 & & 2 & 15 & 10 & \\
\hline & & $4 \%$ & $0 \%$ & $7 \%$ & $54 \%$ & $36 \%$ & 10 \\
\hline \multirow[t]{2}{*}{4} & \multirow[t]{2}{*}{ X2.4 } & & & 4 & 13 & 11 & \\
\hline & & $0 \%$ & $0 \%$ & $14 \%$ & $46 \%$ & $39 \%$ & 10 \\
\hline \multirow[t]{2}{*}{5} & \multirow[t]{2}{*}{$\mathrm{X} 2.5$} & 1 & & 3 & 13 & 11 & \\
\hline & & $4 \%$ & $0 \%$ & $11 \%$ & $46 \%$ & $39 \%$ & 10 \\
\hline \multirow[t]{2}{*}{6} & \multirow[t]{2}{*}{$\mathrm{X} 2.6$} & & & 2 & 15 & 11 & \\
\hline & & $0 \%$ & $0 \%$ & $7 \%$ & $54 \%$ & $39 \%$ & 10 \\
\hline \multirow[t]{2}{*}{7} & \multirow[t]{2}{*}{$\mathrm{X} 2.7$} & & & 3 & 13 & 12 & \\
\hline & & $0 \%$ & $0 \%$ & $11 \%$ & $46 \%$ & $43 \%$ & 10 \\
\hline \multirow[t]{2}{*}{8} & \multirow[t]{2}{*}{$\mathrm{X} 2.8$} & & & 4 & 13 & 11 & \\
\hline & & $0 \%$ & $0 \%$ & $14 \%$ & $46 \%$ & $39 \%$ & 10 \\
\hline \multirow[t]{2}{*}{9} & \multirow[t]{2}{*}{$\mathrm{X} 2.9$} & & & 2 & 15 & 11 & \\
\hline & & $0 \%$ & $0 \%$ & $7 \%$ & $54 \%$ & $39 \%$ & 10 \\
\hline \multirow[t]{2}{*}{10} & \multirow[t]{2}{*}{$\mathrm{X} 2.10$} & & & 3 & 13 & 12 & \\
\hline & & $0 \%$ & $0 \%$ & $11 \%$ & $46 \%$ & $43 \%$ & 10 \\
\hline \multicolumn{2}{|c|}{ JUMLAH } & 2 & 0 & 30 & 136 & 112 & 2 \\
\hline \multicolumn{2}{|c|}{ PERSEN } & $1 \%$ & $0 \%$ & $11 \%$ & $49 \%$ & $40 \%$ & \\
\hline
\end{tabular}

Tanggapan Responden Mengenai Produktivitas kerja

\begin{tabular}{|c|c|c|c|c|c|c|c|}
\hline \multirow[t]{2}{*}{ NO } & \multirow[t]{2}{*}{ Pernyataan } & \multicolumn{5}{|c|}{ Jawaban } & \multirow[t]{2}{*}{ Jumlah } \\
\hline & & STS & TS & KS & $\mathrm{S}$ & SS & \\
\hline \multirow[t]{2}{*}{1} & \multirow[t]{2}{*}{ Y.1 } & & & 6 & 9 & 13 & 28 \\
\hline & & $0 \%$ & $0 \%$ & $21 \%$ & $32 \%$ & $46 \%$ & $100 \%$ \\
\hline \multirow[t]{2}{*}{2} & \multirow[t]{2}{*}{ Y.2 } & & & 4 & 13 & 11 & 28 \\
\hline & & $0 \%$ & $0 \%$ & $14 \%$ & $46 \%$ & $39 \%$ & $100 \%$ \\
\hline \multirow[t]{2}{*}{3} & \multirow[t]{2}{*}{ Y.3 } & & & 6 & 9 & 13 & 28 \\
\hline & & $0 \%$ & $0 \%$ & $21 \%$ & $32 \%$ & $46 \%$ & $100 \%$ \\
\hline \multirow[t]{2}{*}{4} & \multirow[t]{2}{*}{ Y.4 } & & & 4 & 14 & 10 & 28 \\
\hline & & $0 \%$ & $0 \%$ & $14 \%$ & $50 \%$ & $36 \%$ & $100 \%$ \\
\hline \multirow[t]{2}{*}{5} & \multirow[t]{2}{*}{ Y.5 } & & & 6 & 9 & 13 & 28 \\
\hline & & $0 \%$ & $0 \%$ & $21 \%$ & $32 \%$ & $46 \%$ & $100 \%$ \\
\hline \multirow[t]{2}{*}{6} & \multirow[t]{2}{*}{ Y.6 } & & & 3 & 13 & 12 & 28 \\
\hline & & $0 \%$ & $0 \%$ & $11 \%$ & $46 \%$ & $43 \%$ & $100 \%$ \\
\hline \multirow[t]{2}{*}{7} & \multirow[t]{2}{*}{ Y.7 } & & & 4 & 14 & 10 & 28 \\
\hline & & $0 \%$ & $0 \%$ & $14 \%$ & $50 \%$ & $36 \%$ & $100 \%$ \\
\hline \multirow[t]{2}{*}{8} & \multirow[t]{2}{*}{ Y.8 } & & & 3 & 13 & 12 & 28 \\
\hline & & $0 \%$ & $0 \%$ & $11 \%$ & $46 \%$ & $43 \%$ & $100 \%$ \\
\hline \multirow[t]{2}{*}{9} & \multirow[t]{2}{*}{ Y.9 } & & & 4 & 13 & 11 & 28 \\
\hline & & $0 \%$ & $0 \%$ & $14 \%$ & $46 \%$ & $39 \%$ & $100 \%$ \\
\hline \multirow[t]{2}{*}{10} & \multirow[t]{2}{*}{ Y.10 } & & & 3 & 13 & 12 & 28 \\
\hline & & $0 \%$ & $0 \%$ & $11 \%$ & $46 \%$ & $43 \%$ & $100 \%$ \\
\hline \multicolumn{2}{|c|}{ JUMLAH } & 0 & 0 & 43 & 120 & 117 & 280 \\
\hline \multicolumn{2}{|c|}{ PERSEN } & $0 \%$ & $0 \%$ & $15 \%$ & $43 \%$ & $42 \%$ & $100 \%$ \\
\hline
\end{tabular}

\section{Uji Heterokedastisitas}

Uji ini bertujuan untuk menguji apakah dalam sebuah model regresi terjadi ketidaksamaan varians dari residual, dari satu pengamatan ke pengamatan yang lain. Jika varians dari residual dari satu pengamatan ke pengamatan yang lain tetap, maka disebut homoskedastisitas dan jika varians berbeda, disebut heterokedastisitas. Model regresi yang baik adalah tidak terjadi heterokedastisitas. Untuk mendeteksi ada tidaknya heterokedastisitas dapat digunakan metode grafik Scatterplot yang dihasilkan dari output program SPSS versi 16, apabila pada gambar menunjukkan bahwa titik-titik menyebar secara acak serta tersebar baik di atas maupun di bawah angka 0 pada sumbu Y, maka hal ini dapat disimpulkan tidak terjadi adanya heterokedastisitas pada model regresi Ghozali, 2005.

\section{Hasil Pengujian Heterokedastisitas}

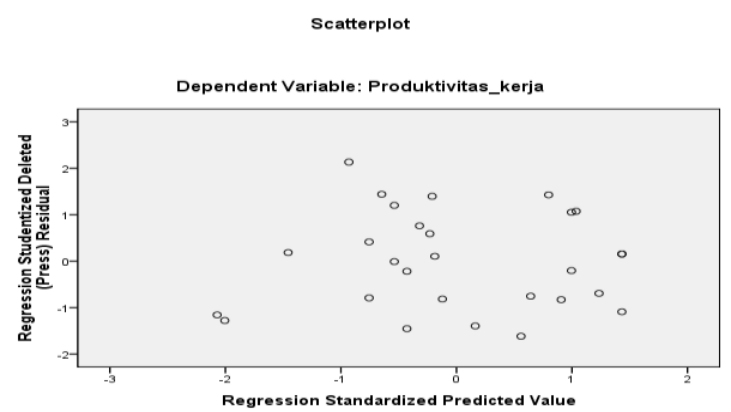

Hasil uji Noprmalitas

Normal P-P Plot of Regression Standardized Residual

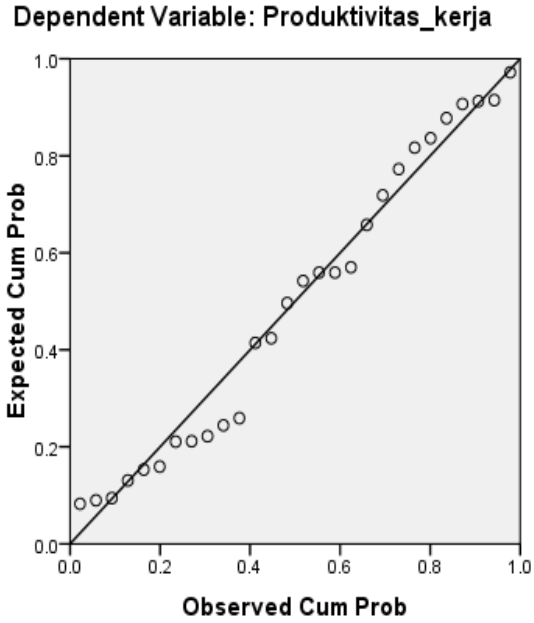

\section{Uji F ( Pengujian hipotesis secara simultan)}

Untuk menguji pengaruh variabel bebas secara bersama-sama diuji denganmenggunakan uji F. Hasil perhitungan regresi secara simultan diperoleh sebagai berikut: 
Koefisien determin

\begin{tabular}{|c|c|c|c|c|c|c|}
\hline \multicolumn{7}{|c|}{ ANOYA ${ }^{\mathrm{b}}$} \\
\hline \multicolumn{2}{|c|}{ Model } & $\begin{array}{l}\text { Sum of } \\
\text { Squares }\end{array}$ & df & Mean Square & F & Sig. \\
\hline 1 & Regression & 640.544 & the & 320.272 & 48.856 & .000 \\
\hline & Residual & 163.884 & 2 & 6.555 & & \\
\hline & Total & 804.429 & 2 & & & \\
\hline
\end{tabular}

\section{Ujit ( Uji Hipotesis Secara Parsial )}

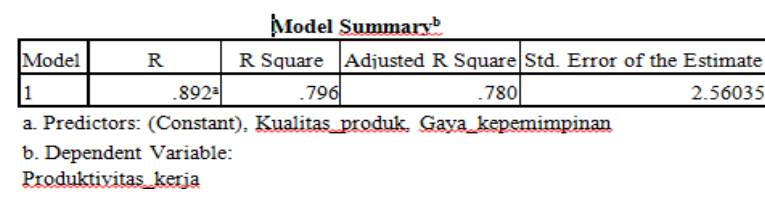

Model Summary

\begin{tabular}{|c|c|c|c|c|}
\hline Model & $\mathrm{R}$ & R Square & Adjusted R Square & Std. Error of the Estimate \\
\hline 1 & $892^{\mathrm{a}}$ & 796 & 780 & 2.56035 \\
\hline
\end{tabular}

Berdasarkan hasil pengujian secara statistik dapat terlihat dengan jelas bahwa secara parsial (individu) tidak semua variabel bebas berpengaruh terhadap variabel terikat.Dimana gaya kepemimpinanmempunyai pengaruh positif terhadap produktivitas kerja, sedangkan kualitas produktidak mempunyai pengaruh positif terhadap produktivitas kerja. Hasil penelitian variable bebas X1sesuai dengan hasil penelitian sebelumnya, sedangkan variable $\mathrm{X} 2$ tidak sesuai. Penjelasan dari masing-masing pengaruh variabel dijelaskan sebagai berikut:

\section{Pengaruh Gaya Kepemimpinan terhadap Produktivitas Kerja}

pengujian hipotesis (H1) telah membuktikan terdapat pengaruh antara gaya kepemimpinan terhadap produktivitas kerja. Melalui hasil perhitungan yang telah dilakukan diperoleh nilai t hitung sebesar 3,071 dengan taraf signifikansi hasil sebesar 0.05masih sama besar dengan 0.05, dengan demikian $\mathrm{Ha}$ diterima dan Hoditolak. Pengujian ini secara statistik membuktikan bahwa gaya kepemimpinan berpengaruh positif terhadap produktivitas kerja. Artinya bahwa ada pengaruh antara variabel gaya kepemimpinan terhadap produktivitas kerja karyawan spray painting metal di PT.Rapala Vmc Batam.

\section{Pengaruh Kualitas Produk terhadap Produktivitas Kerja}

Hasil pengujian hipotesis (H2) telah membuktikan tidak terdapat pengaruh antara kualitas produk terhadap produktivitas kerja. Melalui hasil perhitungan yang telah dilakukan didapat nilai t hitung sebesar 1.656 dengan taraf signifikansi hitung sebesar 0.110 tersebut lebih besar dari 0.05, yang berarti bahwa hipotesis dalam penelitian ini menolak $\mathrm{Ha}$ dan menerima Ho. Pengujian ini secara statistik membuktikan bahwa kualitas produktidak berpengaruh positif terhadap produktivitasa kerja. Artinya bahwa tidak ada pengaruh antara variabel kualitas produk terhadap produktivitas kerja karyawan spray painting metal di PT.Rapala Vmc Batam.

\section{KESIMPULAN}

Berdasarkan hasil "Pengaruh Gaya kepemimpinan dan Kualitas produk terhadap Produktivitas kerja karyawan Spray Painting Metal PT.Rapala Vmc Batam" maka dapat disimpulkan bahwa :

1. Gaya Kepemimpinan berpengaruh signifikan terhadap produktivitas kerja karyawan Spray Painting Metal PT.Rapala Vmc Batam. Hal ini berarti bahwa jika gaya kepemimpinan meningkat maka terjadi peningkatan pada produktivitas kerja karyawan.

2. Kualitas produk tidak berpengaruh signifikan terhadap produktivitas kerja karyawan Spray Painting Metal PT.Rapala Vmc Batam.

3. Gaya kepemimpinan dan Kualitas produk berpengaruh signifikan terhadap produktivitas kerja karyawan Spray Painting Metal PT.Rapala Vmc Batam. Hal ini berarti bahwa jika Gaya Kepemimpinan dan Kualitas Produk meningkat secara bersama-sama, maka akan meningkatnya produktivitas kerja karyawan.

Berdasarkan kesimpulan yang telah dilakukan maka saran yang dapat diberikan dalam penelitian ini yaitu: 


\section{SARAN}

\section{Bagi Perusahaan}

Diharapkan dengan adanya penelitian ini, pada departemen Spray PaintingMetal PT.Rapala Vmc Batam dapat meningkatkan gaya kepemimpinan atasannya dengan demikian produktivitas kerja karyawan pun akan meningkat.

\section{Bagi Penelitian Selanjutnya}

Hasil Uji $\mathrm{R}^{2}$ menunjukkan masih ada variabelvariabel lain yang harus diperhatikan dalam penelitian ini. Penelitian-penelitian lebih lanjut, hendaknya menambah variabel lain yang dapat mempengaruhi produktivitas kerja, karena dengan semakin baik produktivitas kerja yang diberikan maka akan berpengaruh baik juga bagi perusahaan.

\section{REFERENSI}

Thoha, Miftah, 2013, kepemimpinan dalam manajemen, edisi 1, PT RajaGrafindo,. Jakarta.

eithzal Rivai. 2014. Manajemen Sumber Daya Manusia untuk Perusahaan,. Edisi ke 6, PT. Raja Grafindo Persada, Depok, 16956.

Fandy Tijptono, 2004, Strategi Pemasaran, edisi kedua, Andi,. Yogyakarta.

Abdul, Kadir. 2001. Dasar Pemrograman Web Dinamis Menggunakan PHP. Yogyakarta: C.V Andi Offset.

Danang Sunyoto. $2013 . \quad$ Dasar-Dasar Manajemen Pemasaran. Yogyakarta: CAPS.

Hasibuan. (2010). Manajemen Sumber Daya Manusia. Jakarta: Bumi Aksara.

Wibowo (2011). Manajemen Kinerja. Jakarta: PT. Raja Grafindo Persada.

Edy Sutrisno, 2011, Manajemen Sumber Daya Manusia, Jakarta: 